\title{
A CARBONATE RAMP EVOLUTION IN THE TRANSITION FROM THE APULIA PLATFORM TO THE IONIAN BASIN DURING EARLY TO LATE CRETACEOUS (NW GREECE)
}

\author{
Getsos K. ${ }^{1}$, Pomoni-Papaioannou F. ${ }^{2}$, and Zelilidis A. ${ }^{1}$ \\ ${ }^{i}$ University of Patras, Department of Geology,k.getsos@upatras.gr,azelilidis@upatras.gr \\ ${ }^{2}$ National and Kapodistrian University of Athens, Faculty of Geology and Geoenvironment, \\ Department of Hist.Geology-Paleontology,fpomoni@geol.uoa.gr
}

\begin{abstract}
Facies analysis of Cretaceous carbonate sequences from the external and central Ionian zone revealed a homoclinal ramp model of evolution. During Berriasian to Valanginian, the carbonate ramp was differentiated to an inner-mid and outer ramp environment, which corresponded to the external and central Ionian zone, respectively, while the main inner ramp environment is assumed that was located in the Pre-Apulian zone. The external Ionian zone (inner-mid ramp) is characterized by mudstones-wackestones with fragmented echinoderms, bivalves, radiolarians and rare aptychus considered to be deposited below the fairweather wave base (FWWB). Locally, thin graded storm deposits intervene, indicating deposition above the storm weather wave base (SWB). Minor occurrences of packstonesgrainstones, with fragmented echinoderms, calcareous algae, tubiphytes, lagenid foraminifera and rare ooids occur, as well, considered to be deposited at the lowermost part of the inner ramp, near the constantly agitated fairweather wave base (FWWB). The central Ionian zone (outer ramp) is mainly characterized by mudstones-wackestones with abundant radiolarians and rare calpionellids and calcispheres, considered to be deposited below the storm wave base (SWB). No talus or breccias deposits were observed, during the mentioned time interval, in any part of the studied area. From Hauterivian to Turonian, continual sea-level rise, led to establishment of outer ramp environment in the external Ionian zone, over the previous inner-mid ramp, and outer ramp-basin environment, over the previous outer ramp, in the central Ionian zone. The transition from shallower to deeper conditions is characterized by an overall deposition of mudstones-wackestones with abundant radiolarians rooted in pure micrite.
\end{abstract}

Key words: intercalations, facies zones, ramp, sedimentation rates.

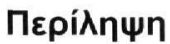

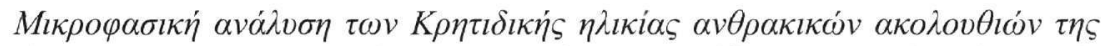

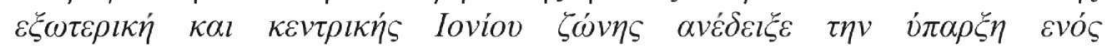




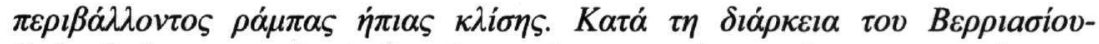

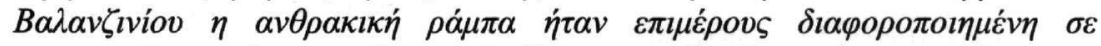

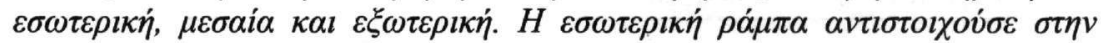

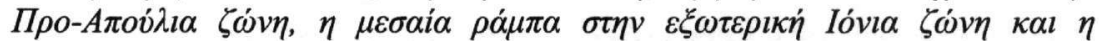

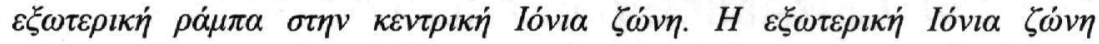

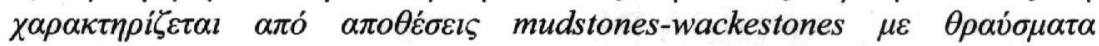

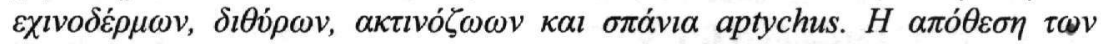

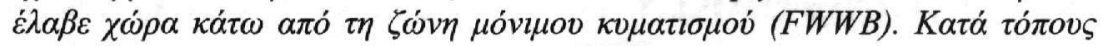

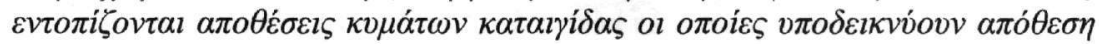

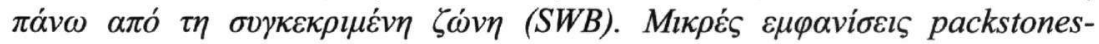

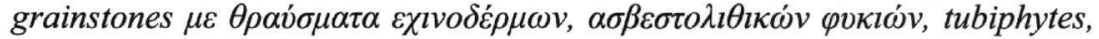

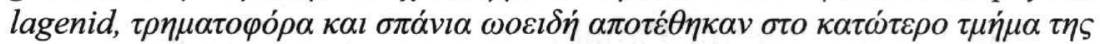

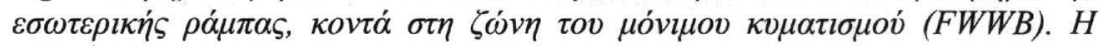

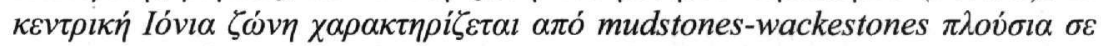

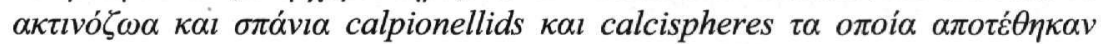

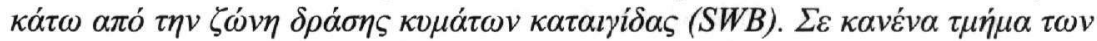
$\mu \varepsilon \lambda \varepsilon \tau \eta \theta \varepsilon \dot{\varepsilon} \tau \omega \nu$ a

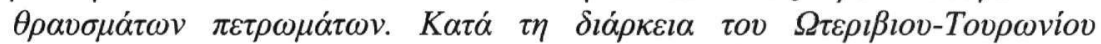

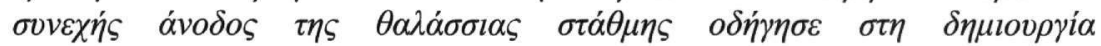

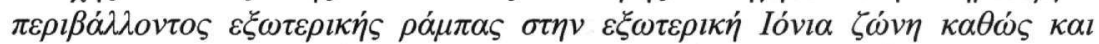

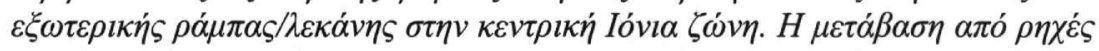

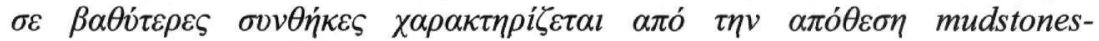

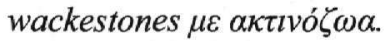

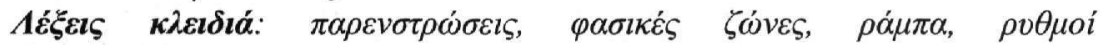

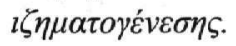

\section{Introduction}

Ionian zone at the Early to Middle Triassic corresponded to a shallow marine platform, which evolved to a vast basin bounded on both sides by shallow platforms; Apulia platform on the west and Gavrovo-Tripolitza platform on the east (Bosellini and Morsilli 1996). The Ionian zone in general has been studied by Aubouin (1959), IGRS-IFP (1966), Bornovas (1961), Bernoulli and Renz (1970), BP (1971), Karakitsios and Tsaila Monopolis (1988), Karakitsios et al. (1988). The Apulian platform has been studied in detail, by Bosellini and Morsilli (1996) and Graziano (2000). Moreover Underhill (1989) suggests that the Pre-Apulia zone in Greece is part of the Apulia platform (Underhill 1989, Fig. 15). The transition from the surrounding Apulia platform to the vast Ionian basin is not clear, yet.

The oldest rocks of the Ionian zone consist of evaporites and dolomites Early to Middle Triassic (Bornovas 1960, Pomoni-Papaioannou 1983, Pomoni-Papaioannou and Tsaila-Monopolis 1983, Pomoni-Papaioannou 1985, Pomoni-Papaioannou et al. 2004, Getsos et al. 2004). Evaporites are overlain by Late Triassic-Early Jurassic typical internal platform-type limestones, in the upper part of which pelagic limestones have been identified, the so-called Siniais limestones (Renz 1955, IGRS-IFP 1966, BP 1971, Karakitsios and Tsaila-Monopolis 1988). During the Toarcian and on, the pelagic sedimentation continues with the deposition of lower Posidonia shales and filamentous limestones (Karakitsios 1990). The upper Posidonia shales represent deposition during the Callovian-Tithonian interval.

During the Berriasian-Santonian p.p., pelagic sedimentation prevailed, giving rise to the Vigla Limestone Formation (les calcaires de Vigla; Aubouin 1959, Karakitsios and Koletti 1992, Karakitsions et al. 2004). Depositional conditions changed during the late CampanianMaastrichtian interval, when clastic material from the basin margins and the neighbouring zones invaded the basin forming limestone beds, described by Aubouin (1959) as "les calcaires 
microbrechiques". During the Paleocene and Eocene, carbonate sedimentation prevailed. Finally, at the end of the Eocene clastic sedimentation was established (Zelilidis et al. 2003) (Fig. 1).

The studied Early to Late Cretaceous Vigla's formation appear as extensive outcrops of thin to medium bedded limestones with an average thickness of $200-400 \mathrm{~m}$. Samples were collected from fifteen outcrops and were studied under a polar microscope (Fig. 2). For the description of the samples, the Dunham's (1962) classification was used, whereas for the determination of the depositional environments, the Standard Microfacies Types (SMF) and Facies zones classifications, after Flugel (1972) and Wilson (1975), were used. The present work aims to improve the sedimentological and stratigraphical knowledge of the early to late Cretaceous carbonate sediments of the Ionian zone and consequently the environmental and palaeogeographic evolution of the Mesozoic Ionian basin. Preliminary work was presented at ISC 7 in Neuchâtel (Getsos et. al. 2005).

\section{Age determination}

The age determination was contacted using microfossils in combination with nannofossils. The samples were chosen carefully in order any misinterpretation, caused by redeposited fossils, to be eliminated. Aptian and ConiacianSantonian epochs are not easily detectable due to the absence of important fossils from the study area. According to the studied fossils Vigla's limestones deposition took place in the Berriasian to Turonian time interval.

More precisely Berriasian age was documented by nannofossils, Nannoconus kamptneri kamptneri, $N$. dolomiticus, $N$. broenimanni, Cyclagelosphaera deflandrei, Diazomatolithus lehmanni, Ellipsagellosphaera britannica, Zeugrhabdothus embergeri and microfossil Calpionella alpina studied in wackestones and

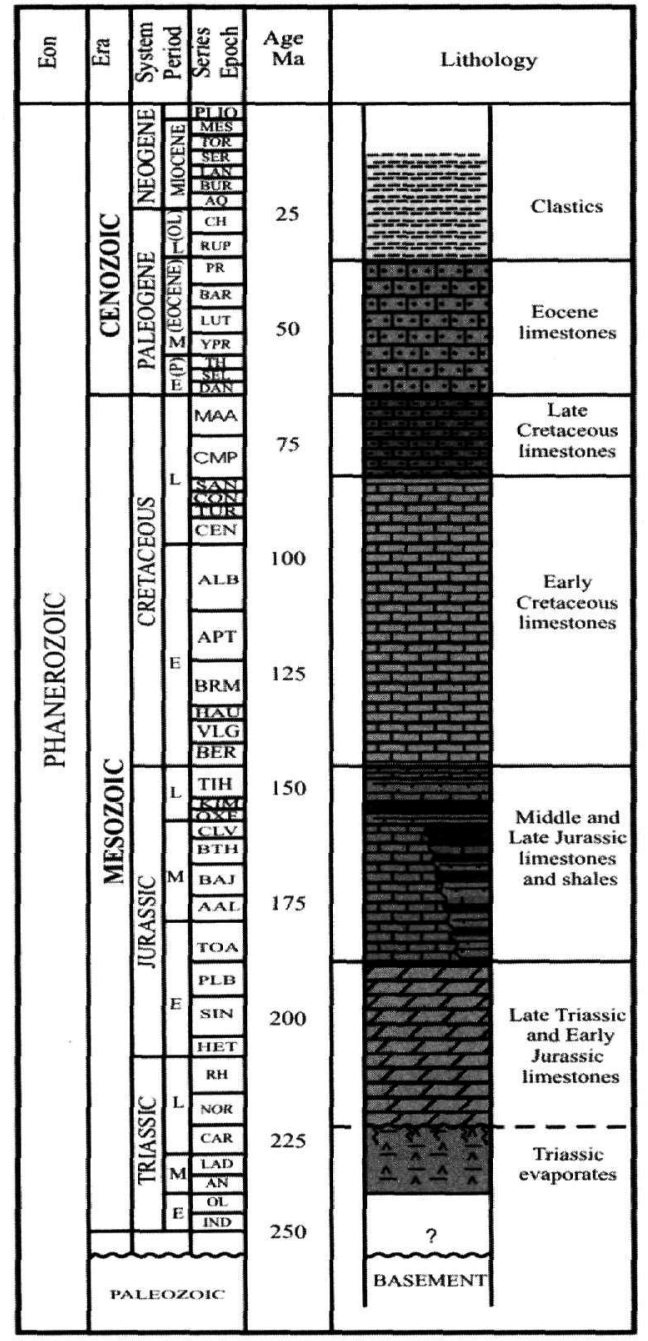

Figure 1 - Stratigraphy of the Ionian zone. The geologic time scale follows the Gradstein et al. (2004) time-scale (modification by Zelilidis et al. 2003) wackestones-packstones. Valanginian age was documented by nannofossils Cruciellipsis cuvillieri, Watznaueria barnesiae, Cyclagelosphaera deflandrei, Nannoconus quadratus, Nannoconus bermudezii (Valanginian-Barremian), Nannoconus broenimanni (up to Valanginian), Nannoconus steinmanni steinmanni, Nannoconus steinmanni minor, Nannoconus colomi, Assipetra infracretacea and microfossils Trocholina, Textularid and Lenticulina. Valanginian-Hauterivian age was documented by nannofossils Conusphaera mexicana mexicana - abundant, Cyclagelosphaera margerelii, Nannoconus bermudezii, Nannoconus cf. Cornuta and HaterivianBarremian age by nannofossils Zeugrhabdotus embergeri, Assipetra infracretacea, Lithraphidites carniolensis, Watznaueria barnesiae. Albian age was documented by Rotalipora and Planomalina buxtorfi, Cenomanian by Globigerinid, Hedbergella and Gumbelina and Turonian by Globotruncana 


\section{Ramps}

Carbonate ramps are divided into two groups, homoclinal and distally steepened with a usually offshore slope break between shallow ramp and basin. Ramps and distally steepened ramps have many common characteristics and for that reason it is difficult to be distinguished in the rock record, without the presence or absence of slope or slope apron deposits, respectively. This distinction is additionally hindered due to post-sedimentary tectonism.

Ramp classification is based on two critical interfaces: the fair-weather wave base (FWWB) and the storm wave weather base (SWB). Although these boundaries occur in various depths, in relation to local hydrodynamic and climatic conditions, the sedimentary features that they define are easily distinctive. According to Burchette and Wright (1992), ramps are divided to three parts: the inner ramp, the mid-ramp and the outer ramp.

The inner ramp is located above the fair-weather wave base (FWWB) being dominated by shoals, organic barriers or shoreface deposits. The mid-ramp is located between the fair-weather wave base (FWWB) and the storm wave weather base (SWB), where the sea floor is affected by storm waves. A variety of storm related features occur, such as graded beds and hummocky crossstratification. Proximal and distal trends can be recognized in mid-ramp deposits (Aigner 1984, Burchette 1987, Faulkner 1988). The outer ramp is located between the lower limit of mid-ramp, where most storms influence the sea floor, and the basin plain. Storm reworking of the sediments is rare, although storm deposits are possible to occur in the upper part (Aigner 1984, Calvet and Tucker 1988). In deeper parts of the zone, restricted conditions may develop, especially in accordance to suboxic basinal sediments. The characteristics of the basinal sediments depend on the depth and nature of the basin itself. They usually lack coarse "tempestites" and turbidites are mostly absent.

\section{Sedimentary remarks}

Sampling localities are shown in Fig. 2. The studied outcrops were grouped into three areas, based mainly on geographical and sedimentological criteria. The area 1 covers the western part of the study area and contains five outcrops, sites $26,23,24$, 44 and 21 , area 2 is located in the middle part and includes the sites 13, 7,9 and 10 , and area 3 at the eastern part and includes the sites 27, 41, 42 and 43 (Fig. 2).

\subsection{Macroscopic description}

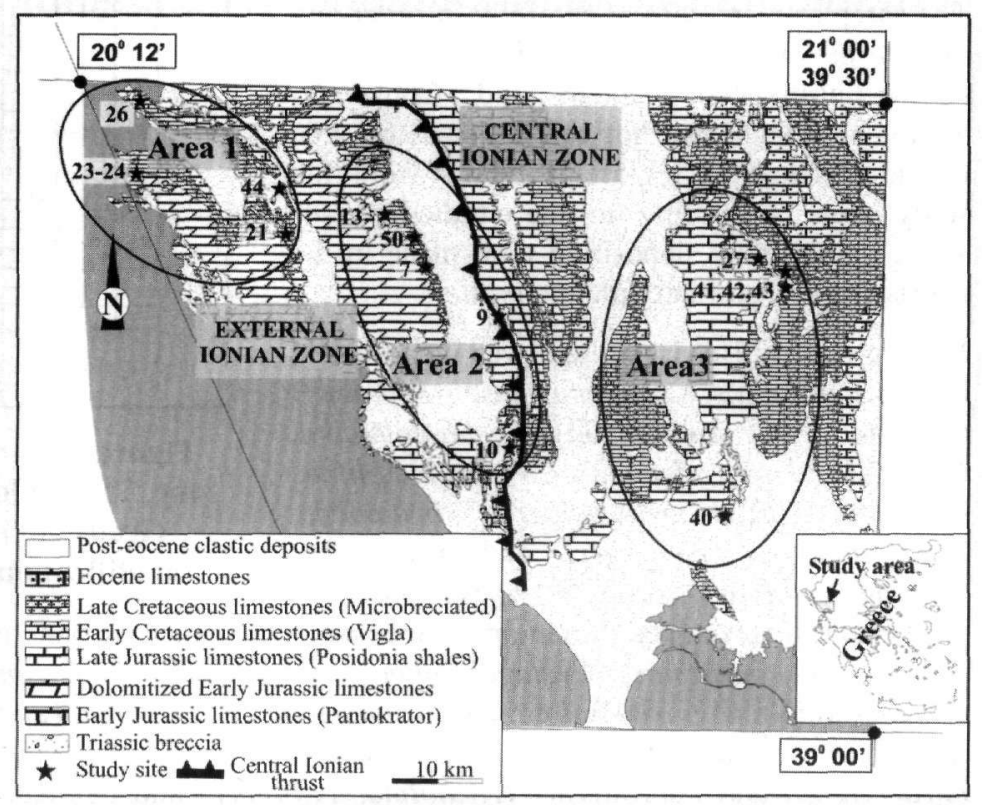

Figure 2 - Geological map of the studied area

A common characteristic found in all studied sequences is that they are consisted of typical pelagic limestones organized in 50-60 cm thick packages. Each package is consisted of five to six thin to 
medium bedded limestones. Furthermore there are siliceous rocks usually in lenses and many times in bed-like-form between beds of limestones.

\subsubsection{Area 1}

In site 26 (locality Liotribia) the Early Cretaceouslimestones were studied in a thick lithostratigraphic column, averaging $280 \mathrm{~m}$ in thickness, consisted of thin to medium bedded pelagic limestones, where thin intercalations of coarse-grained packstones intervene. The whole outcrop is characterized by packets of five to six thin beds and varying total packet thickness ranging from 40 to almost 60 centimeters. In the upper part thick-bedded packstones-grainstones occur.

In sites 23, 24 (locality Plataria) the Early Cretaceouslimestones were studied in a lithostratigraphic column of $150 \mathrm{~m}$ in thickness. The whole sequence is consisted of 50-60 centimeter thick packets of thin to medium bedded limestones.

In sites 44, 21 (locality Karterion) the typical of E.Cetaceous age, outcrops are consisted of 50-60 centimeter thick packets containing thin to medium bedded limestones. The average thickness do not exceeds 100 meters in both sites.

\subsubsection{Area 2}

In sites 13, and 10 (localities Karbounarion, Boubopotamon and Skepastos) the typical sequences of Early Cretaceous ( Beriassian-Valanginian - Sites 13,10), are consisted of ordinary packets with medium to thin bedded limestones. The lithostratigraphic column in its locality does not exceed 100 meters in thickness.

In site 9 (locality Skandalon) the Late Cretaceous (Cenomanian-Turonian) sequence is consisted of medium to thin bedded limestones organized in 50-60 centimeters thick packets with five to six 510 centimeters thick, internal beds. Total lithostratigraphic column is 100 meters in thickness.

\subsubsection{Area 3}

In sites 27, $41 \& 42$ (Berriasian-Valanginian) and 43 (Hauterivian-Barremian) (locality Kouklesi) the Early Cretaceouslimestones were studied in a lithostratigraphic column averaging $150 \mathrm{~m}$ in thickness and consisted of typical pelagic limestones organized in 50-60 centimeters thick packages.

\subsection{Microscopic description}

The prevailing microfacies type in the study area was determined as SMF 3 with interventions of SMF 4.

The main microfacies types in area 1 are consisted of mudstones-wackestones with sparse, whole shelled foraminiferas rooted in pure micrite, determined as SMF 3 (Fig. 3A). The intercalations are commonly consisted of packstones with rare lithoclasts, abundant bioclasts and whole shells of benthic foraminiferas, echinoderms, bivalves and sometimes algae determined as SMF 4 (Figs 3B, C). Under microscope these intercalations are usually observed with a characteristic structure consisted of millimeter-scale packstones at the base passing gradually into wackestones with fine bioclasts and lithoclasts. Finally, the millimeter-scale sequence pass to an end member of mudstones with seattered pelagic foraminiferas. At the top of the outcrop (end of Berriasian) there are grainstones with lithoclasts from older limestones, echinoderms and algae, determined as SMF 4 (Fig. 3C).

The unique microfacies type in the whole sequence studied in area 2 is mudstone-wackestone with scattered pelagic foraminiferas determined as SMF 3 (Fig. 3D). Moreover site 7 has a special characteristic made up from red and grey colored intercalations and cross lamination without any other, distinct lithological differentiation (Fig. 3F). 
The prevailing microfacies in area 3 are mudstones-wackestones with scattered pelagic foraminiferas (SMF 3). Within the above mentioned mudstones-wackestones there are thin laminae consisted of packstones with abundant intraclasts. In places a millimeter-thick microsequence consisted of unlaminated intraclastic packstone at the base, unlaminated wackestone in the middle and laminated wackestone at the top, has been observed (Fig. 3E). Furthermore, color differentiated lamination were studied with great similarity to those of area 2 .

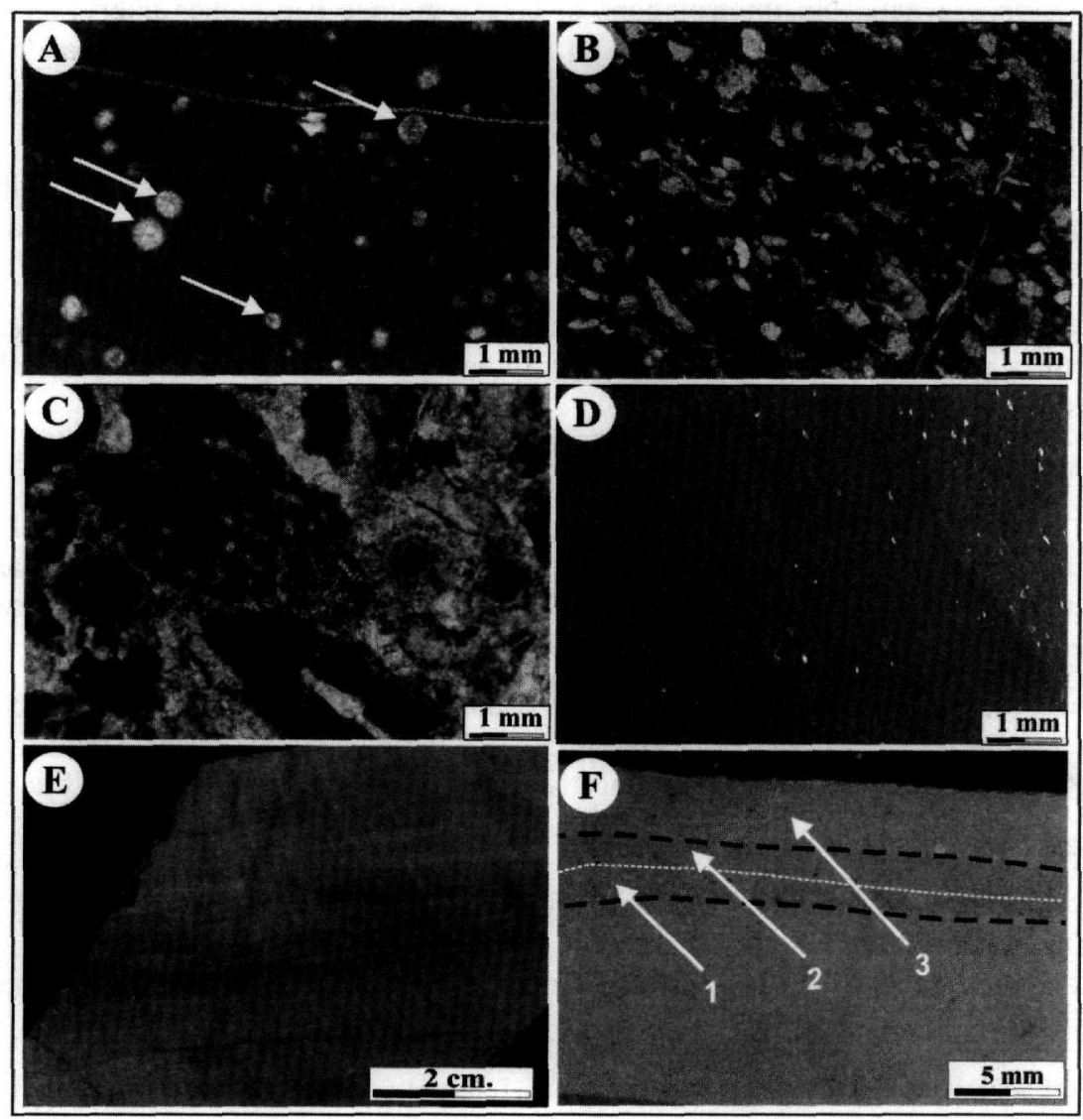

Figure 3 - A) scattered radiolarians rooted in micrite, B) packstone with bioclasts and lithoclasts, C) grainstone-rudstone, $D$ )mudstone - end member of $\mathrm{mm}$ scale sequence, $E$ ) 1:packstone, 2: laminated wackestone, 3: cross laminated wackestone, E) color differentiated lamination

\subsection{Interpretation}

The studied rocks in area 1, of Early Cretaceous (Berriasian-Valanginian) age, are typical of a HST ("highstand" system tract) with various short term sea level falls. The intercalations were interpreted as gravity flows with distal and proximal trends, cryptoturbidites or tempestites. The depositional environment of the SMF 3 was interpreted as deep shelf margin (FZ 3) and the SMF 4, consisted of packstones, as distal foreslope (FZ 4), while the grainstones as proximal foreslope. The depositional profile during Early Cretaceous (Berriasian-Valanginian) corresponds to a middle ramp environment with a minor occurrence of inner ramp at the end of Berriasian, while the grainstones were deposited (Fig. 4). The proximal foreslope environment, inner ramp, coincides with an almost $50 \mathrm{~m}$ sea level fall (Haq et al. 1987). Moreover, grainstone deposition is indicative of the FWWB zone, while the above mentioned intercalations can be determined as deposition 
within SWB zone. During Hauterivian-Turonian, rock record shows sedimentation in much more quiet conditions as none resedimented fragment was studied up to Turonian.

The depositional environment in area 2 during Early to Late Cretaceous was interpreted as deep shelf margin or open sea shelf (FZ 3,2). The color differentiated lamination was correlated with fluctuations of the oxygenation level. The depositional profile corresponds to outer ramp (Fig. 4). The ramp in this area should bear a very gentle inclination towards basin, as no resedimented material was studied.

The depositional environment in area 3 during Early to Late Cretaceous was determined as deep shelf margin (FZ 3) and the lamination was deposited through low density gravity flows, crytpoturbidites, or from distal storm waves, tempestites. The color differentiated lamination was caused by deposition at oxygenation level. The absence of shallow marine material from the coarse lamination (SMF 4) suggests deposition far away from the shelf environment. The depositional profile corresponds to outer ramp (Fig. 4).

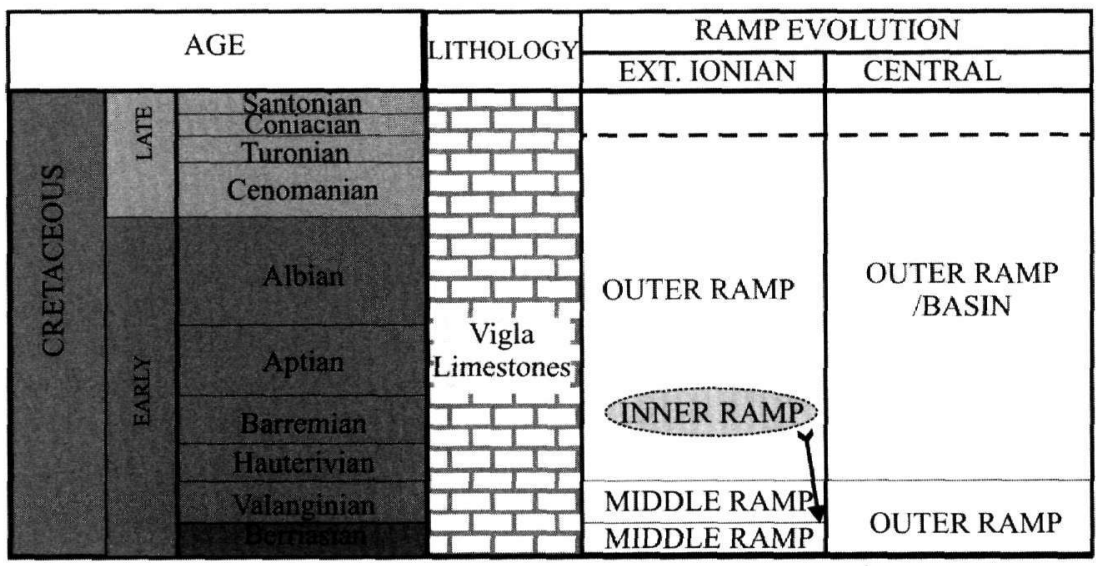

Figure 4 - Ramp evolution during Early to Late Cretaceous

\section{Estimation of sedimentation rates}

The thickness of the Vigla's limestones in the studied area varies between 50 and $500 \mathrm{~m}$. The strata in general are thickening from the Ionian basin towards the Apulian platform in the west, especially during specific time intervals. For instance, during Berriasian to Valanginian there is a big differentiation in thickness of the strata between external and central Ionian zone. In study area 1 the thickness of the deposited sediments during Berriasian to Valanginian exceeds $300 \mathrm{~m}$ while in the same time in study area 2 the thickness is almost $200 \mathrm{~m}$. and in study area 3 the thickness is only $100 \mathrm{~m}$. (Fig. 5). During Hauterivian to Turonian, the difference in thickness is maintained but the values are reduced, $150 \mathrm{~m}$. in area 1 to maximum $50 \mathrm{~m}$. in area 3 . Taking into account the above mentioned thicknesses and considering the duration of every epoch in thousands years (Gradstein et al. 2004) annual sedimentation rate was estimated. The sedimentation rates during Berriasian - Valanginian time interval are $37 \mathrm{~mm} / \mathrm{ka}, 22 \mathrm{~mm} / \mathrm{ka}$ and $11 \mathrm{~mm} / \mathrm{ka}$ for areas 1,2 and 3 , respectively. The sedimentation rates for the Hauterivian - Turonian time interval are $3 \mathrm{~mm} / \mathrm{ka}, 2$ $\mathrm{mm} / \mathrm{ka}$ and $1 \mathrm{~mm} / \mathrm{ka}$ for areas 1,2 and 3 respectively. It is obvious that a three times faster sedimentation rate was maintained during the studied time interval, Berriasian-Turonian, between area 1 and area 3. Moreover the sedimentation rate was decreased gently from area 1 to area 3 through area 2 . It can be concluded that the sedimentological system had the tendency to become aggradational due to the difference in sedimentation rate between area 1 and areas 2,3. The studied high sedimentation rate in area 1 was probably due to high organic productivity, usual in shallow areas. 


\section{Discussion}

The performed sedimentological study revealed that the Berriasian Valanginian sediments were deposited on a homoclinal ramp system. The sediments which are nowadays located to the external Ionian zone (area 1) were deposited in middle ramp and less in the lower limit of the inner ramp. Mudstones and wackestones with thin intercalations of packstones correspond to deposition in the middle ramp between FWWB and SWB. The lower limit of the inner ramp probably had occurred for a short period of time in the late Berriasian thus the thickness of the rock record is up to 10-12 meters. This deposit is consisted of grainstones with resedimented clasts of older limestones and benthic foraminiferas. The deposition of these limestone documents a short term eustatic sea level fall occurred in the transition from Berriasian to Vlanginian (Haq et. al. 1987). In the same time interval the sediments

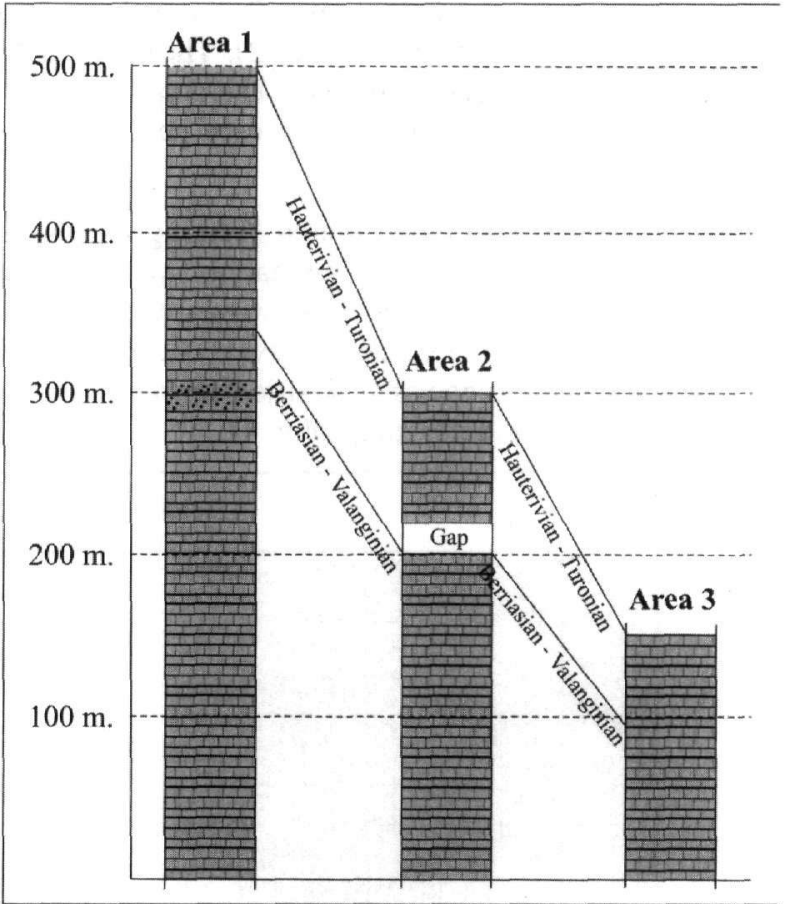

Figure 5 - Stratigraphy of the study area, all the sections are in scale which are nowadays located in the central Ionian zone (areas 2, 3) were deposited in outer $\mathrm{ramp} / \mathrm{basin}$ environment as the storm reworking is rare and in much less extent than area 1. During Hauterivian to Turonian the sedimentation pattern was the same for the external and central Ionian zone and it is typical of outer ramp/basin environment as is indicative of the rare storm reworking and the periodically occurrence of red and grey colored lamination. These lamination are in accordance with the suboxic or anoxic conditions which occur in the deeper parts of the outer ramp and basinal environment (Fig. 6). Thus it can be concluded that the ramp system was drowned during the above mentioned time interval.

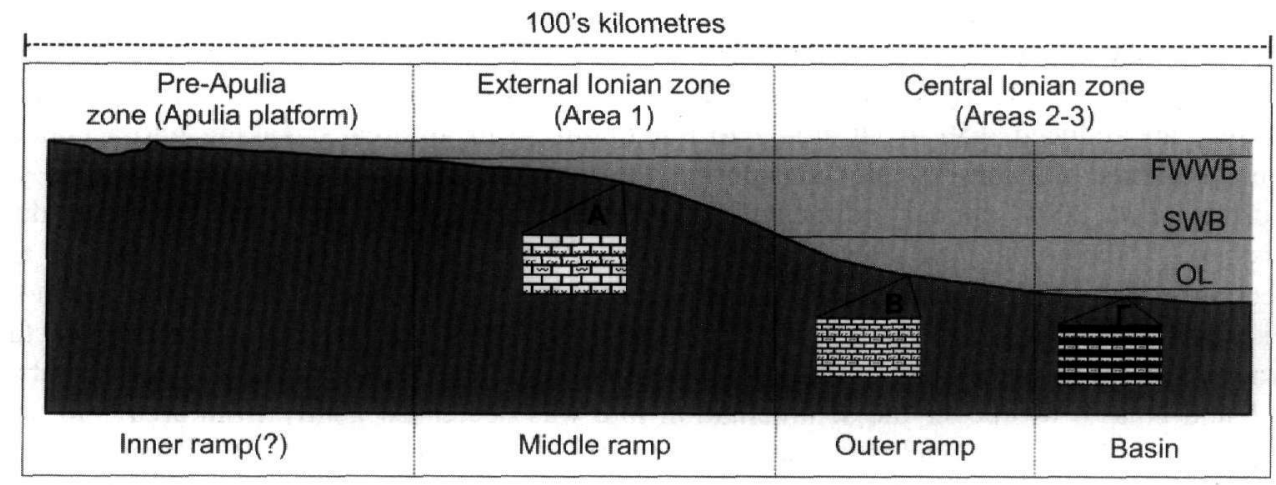

Figure 6 - Two- dimensional figure of the external and central Ionian and pre-Apulian zones during the Cretaceous 
The Ionian zone is interpreted as a deep basin adjacent to the Apulia platform. The existence of pre-Apulia zone (Apulian platform) which is characterized by thick platform facies in correlation with the differences in sedimentation studied in this work can prove the presence of a homoclinal ramp system. The absence of any talus deposit from the studied area and presented sedimentological record show that the transition from the Apulia platform to the Ionian basin was a homoclinal ramp.

The high sedimentation rates for the Berriasian - Valanginian time interval are indicative of high organic productivity which show a gradual decrease towards the central Ionian zone (Ionian basin?). In addition to the gentle inclination from the Apulia platform towards the Ionian basin eastwards, the system had the tendency to become aggradational. This gradual decrease is maintained during Hauterivian - Turonian time interval but in much slower rate. The higher sedimentation rate over shallower areas is attributed to the greater organic productivity.

\section{Conclusions}

During Berriasian to Valanginian the main facies of the external Ionian zone (area 1) were mudstones-wackestones and abundant intercalations of packstones-grainstones with resedimented fragments. Instead, in the central Ionian zone during the above mentioned period mudstoneswackestones with scattered foraminiferas, mainly radiolarians, were deposited with rare intercalations of packstones. During Hauterivian to Turonian the sedimentation pattern was the same for the external and central Ionian zone and the main facies were mudstones wackestones with scattered pelagic foraminiferas and radiolarians. The depositional environment was corresponded to foreslope with proximal and distal trends, deep shelf margin, open sea shelf and basin (den anafereis tetoia perivallonta sto keimeno, oute sto Discussion). The above depositional environments, during Berriasian-Valanginian, correspond to a middle ramp environment with a minor occurrence of inner ramp for the external Ionian zone, (area 1), and to an outer ramp-basin for the central Ionian zone (areas 2 and 3). The transition from the Apulian platform to the adjacent Ionian basin was of a homoclinal ramp type. During Berriasian to Valanginian the sediments were deposited on two different parts of a homoclinal ramp system. It was middle and outer-basin environment which during Hauterivian to Turonian was drowned and outer ramp-basin was established.

The estimated sedimentation rates are much higher in the area 1 than the areas 2 and 3 in the whole time interval. The difference in sedimentation rates between Berriasian - Valanginian and Hauterivian - Turonian time intervals is caused by the differences in organic productivity over the different parts of the ramp. The differences in sedimentation rates for middle and outer ramp show that the homoclinal ramp system was moving towards aggradational settings.

\section{References}

Aigner, T., 1984. Dynamics of intercratonic carbonate ramps, Upper Muschelkalk, (Middle Triassi c), South-German Basin, 7th Meeting of Carbonate Sedimentologists, Liverpool.

Aubouin, J., 1959. Contribution a l'etude geologique de la Grece septentrionale: les confins de l'Epire et de la Thesallie, Annales Geologique des Pays Helleniques, 10, 870-885.

Bernoulli, D., and Renz, O., 1970. Jurassic Carbonate Facies and New Ammonite Faunas from Western Greece, Ecl. Geol. Hel., 63/2, 573-607.

Bornovas, J., 1961. Observations nouvelles sur la geologie des zones preapulienne et ionienne (Grece occidentale), Bull. Soc. Geol. France, series 7, II/4, 410-414.

Bosellini, A., and Morsilli, M., 1997. A Lower Cretaceous drowning uncomformity on the eastern flank of the Apulia Platform (Gargano Promontory, southern Italy), Cretaceous Research, $18,51-61$. 
British Petroleum Co. Ltd. (BP), 1971. The geological results of petroleum exploration in western Greece, Instit. Geol. Sub. Res., Special report 10.

Burchette, T.P., and Wright, V.P., 1992. Carbonate ramp depositional systems, Sedimentary Geology, 79, 3-57.

Calvet, and Tucker, M., 1988. Outer ramp cycles in the Upper Muschelkalk of the Catalan Basin, northern Spain, Sedimentary Geology, 57, 185-198.

Dunham, R.J., 1962. Classification of carbonate rocks according to depositional texture, Memoir, American Association of Petroleum Geologists, 1, 108-121.

Flugel, E., 1972. Mikrofazielle Untersuchungen in der Alpinen Trias. Methoden and Probleme, Mitt. Ges. Geol. Bergbaustud. 21, 9-64.

Getsos, K., Pomoni-Papaioannou, F., and Zelilidis, A., 2004. Triassic carbonate and evaporite sedimentation in Ionian zone (western Greece): palaeogeographic and palaeoclimatic implication, Bulletin of the Geological Society of Greece, XXXVI, 699-707.

Getsos, K., Pomoni-Papaioannou, F. and Zelilidis, A., 2005. A carbonate ramp type differentiation of the western Ionian basin during early to late Cretaceous (NWGreece), $7^{\text {th }}$ International Symposium on the Cretaceous, Abstracts, 132.

Gradstein, F.M., Ogg, J.G., Smith, A.G., Bleeker, W., and Lourens, L.J., 2004. A new geologic time scale with special reference to Precambrian and Neogene, Episodes, 27, 83-100.

Graziano, R., 2000. The Aptian-Albian of the Apulia Carbonate Platform (Gargano Promontory, southern Italy): evidence of palaeoceanographic and tectonic controls on the stratigraphic architecture of the platform margin, Cretaceous Research, 21, 107-126.

Haq, B.U., Hardenbol, J., and Vail, P.R., 1987. Chronology of Fluctuating Sea Levels Since the Triassic, Science, 235, 1156-1167.

IGRS-IFP, 1966. Etude gélogique de l'Epire (Gréce nordoccidentale), Ed. Technip, Paris, 306pp.

Karakitsios, V., 1990. Study of Jurassic age paleofaults in Ionian zone (Epirus, Greece), Proceedings of the $5^{\text {th }}$ international Congress, XXV/1,307-318.

Karakitsios, V., 1992. Ouverture et inversion tectonique du basin ionien (Epire, Grece). Annales Geologique des Pays Helleniques, 35, 85-318.

Karakitsios, V., and Tsaila-Monopolis, S., 1988. Donnees nouvelles sur les niveaux superieurs (Lias inferieur - moyen) des calcaires de Pantokrator (Zone Ionienne moyen, Epire, Grece contenentale) description des calcaires de Louros (New data from the upper part (early middle Lias) of the Pantokrator limestone (middle Ionian zone, Epirus, continental Greece) description of Louros limestone), Rev. de Micropaleontologie, 31(1), 49-55.

Karakitsios, V., Danelian, T., and De Wever, P., 1988. Datation par les radiolaires des Calcaires á Filaments, Schists á Posidonies superieurs et Calcaires de Vigla "zone Ionienne, Epire, Gréce", du Callovient au Tithonique terminal, Compte Rendu de l'Académie des Sciences, 306/II, 367-372.

Karakitsios, V., and Koletti, L., 1992. Critical revision of the age of the basal Vigla limestones (Ionian zone, western Greece), based on nannoplankton and calpionellids with paleogeographical consequences. In B. Hamrsmid and J. Young (eds), Proceedings of the Forth International Nannoplankton Association Conference, Prague, 1991, Knihovnicka ZPN, 14a, vol. 1, p. 165-177. 
Karakitsios, V., Tsikos, H., Van Breugel, Y., Bakopoulos, I., and Koletti, L., 2004. Cretaceous oceanic anoxic events in western continental Greece, Bull of the Geol. Soc. Greece, XXXVI, 846-855.

Pomoni, F., 1983. Studiul petrographic si sedimentologic al evaporitelor Triasice din regiunea Epir, Teza de Doctorat, Universitatea Bucuresti, 1-190pp.

Pomoni-Papaioannou, F., 1985. The sedimentology and depositional environment of the Triassic dolomite-gyprum facies of western Greece, Proceedings of the $6^{\text {th }}$ European Meeting of the Inter. Assoc. Sedimentologists, 367-368.

Pomoni-Papaioannou, F., Karakitsios, V., Kamberis, E., and Marnelis, F., 2004. Chevron-type halite and nodular anhydrite in the Triassic Evaporitic Formation of the Ionian Zone (Western Greece), Proceedings of the 10th International Congress,Bulletin of the Geological Society of Greece, XXXVI, 578-586.

Renz, C., 1955. Die vorneogene Stratigraphie der normal-sedimentaren Formationen Griechenlan, Inst. Geol. Susururf. Res. Athens, 637.

Underhill, J.R., 1989. Late Cenozoic deformation of the Hellenide foreland, western Greece, Geological Society of America, Bulletin, 101, 613-634.

Wilson, J.L., 1975. Carbonate Facies in Geologic History, Berlin-Heidelberg-New York (Springer), 471p.

Zelilidis, A., Piper, D. J., Vakalas, I., Avramidis, P., and Getsos, K., 2003. Oil and Gas Plays in Albania: Do Equivalent Plays Exist in Greece? Journal of Petroleum Geology, 26, 29-48. 